\title{
8, Dr Fanon on Colonial Narcissism and Anti-Colonial Melancholia
}

\section{Colin Wright}

Frantz Fanon is known as a theorist of anti-colonial resistance and decolonisation who put his ideas into practice during the Algerian war of independence. However, what is often forgotten or passed over far too quickly is his training and innovative practice as a psychiatrist, despite the central role both evidently play in his critique of the dehumanising effects of racism and colonial oppression.

This chapter provides an outline of Fanon's involvement in the most progressive strand of French psychiatry that became known as 'psychothérapie institutionnelle', as well as of his clinical response to the colonial context at the Bilda-Joinville hospital in Algeria, in order to demonstrate the strong continuities between his psychiatric practice on the one hand, and his critical writings and political activism on the other. This brief portrait of 'Dr Fanon' paves the way for a discussion of the impact of the Freudian concepts of narcissism and melancholia on his two best known works. Firstly, I discuss his use of Jacques Lacan's mirror stage argument in the theory of colonial narcissism developed in Black Skin, White Masks (Fanon: 1986). Secondly, I extract from the later text, The Wretched of the Earth (Fanon: 2001), a notion of 'colonial melancholia' which accounts for the collective self-loathing and internecine violence Fanon observes amongst colonised blacks, as well as for the individual 'reactionary psychoses' he describes in its final chapter on 'Colonial War and Mental Disorders'. Finally, I argue that through his critical (re)deployments of narcissism and melancholia, Dr Fanon controversially comes to prescribe revolutionary violence and the creation of a new militant national community as a means of 'treatment' for the subjective yet always also social ailments. 


\section{The Fanon We (Think We) Know}

Frantz Fanon is rightly celebrated as one of the key intellectuals of the $20^{\text {th }}$ century. His searing critique of racism and colonialism not only inspired decolonisation movements around the world, but has also become an indispensable reference point for a whole field of interdisciplinary academic research today in 'postcolonial studies'. It would be strange indeed to encounter a university course on postcolonial theory that did not list either Black Skin, White Masks or The Wretched of the Earth as essential reading (in every sense). In these and other texts by Fanon, one encounters a tone of righteous fury tempered, but also focussed, by an incisive intellect.

Yet Fanon impresses as much by his actions as by his words. Despite his origins in a bourgeois family on the tranquil island of Martinique, Fanon was, by the mid-1950s, far from the Caribbean in North Africa where he became an active member of Algeria's Front de Libération Nationale (FLN). He was thus centrally involved in one of the bloodiest of all the mid-century independence struggles. He was expelled from Algeria by the French government and placed on their most wanted list by its secret police. He survived several assassination attempts, including a bomb which blew up his jeep and left him with twelve fractured vertebrae (Alessandrini: 1999, 4). In these extreme conditions he still managed to write about the liberation struggle vividly enough to have one of his books - L'An $V$ de la Révolution Algérienne (translated into English as $A$ Dying Colonialism) - banned by a French government clearly worried about its power to fan the flames of anti-colonialism, at home as well as abroad. It is this image of the (black) man of letters who was also a (black) man of action that dominates the reception of Fanon today. The romantic pathos of this image was secured by his early death, from leukemia, at the age of only 36 . 
Not surprisingly, the dramatic dénoument to Fanon's life has led to a skewed retrospective view of it, as if down the wrong end of a telescope. In particular, what is obscured by the glare of Fanon-the-revolutionary is his professional training, his innovative clinical practice, and his theoretical writings as a psychiatrist. Perhaps because of the complex entanglements and collusions between European psychiatry and its imperial project, including a dovetailing of pathologisation and racialisation (Keller: 2007), this aspect of Fanon's life and work has sometimes been passed over in slightly embarrassed silence, or reduced to a mere biographical stepping stone on the way to the 'true' Fanon. Much is made, for example, of his resignation from his post at the BildaJoinville hospital in Algeria in 1956. His letter of resignation, reproduced in Towards the African Revolution (1967: 52-54), does indeed show that he felt the practice of psychiatry in such a colonial society to be ethically untenable. There were pragmatic as well as ethical reasons behind this resignation in fact, yet it is often presented as an equivalent to Caesar crossing the Rubicon, as if Fanon had to stop being a psychiatrist to become a revolutionary.

However, I would argue that this does a serious disservice to the extent to which Fanon's clinical and critical thinking was thoroughly shaped by a strand of radical French psychiatry we in the Anglophone world might more readily associate with the (problematic) term 'anti-psychiatry', ${ }^{1}$ with its simultaneous debt to, and criticisms of,

\footnotetext{
${ }^{1}$ Problematic in that the term was invented as a pejorative by mainstream British psychiatrists threatened by the unorthodox ideas that came to be associated with Michel Foucault, Thomas Szasz, R. D. Laing and David Cooper amongst others. The 'anti' part also implies a misleading external opposition to psychiatry as such, whereas the movement's power arguably lay in internal radicalisation in the name of a renewed psychiatry. There are also problems with placing the social constructivism of the libertarian Thomas Szasz
} 
psychoanalysis. I want to give a little room to Dr Fanon the psychiatrist here, because it will provide a context for my subsequent claim that the Freudian (or Freudo-Lacanian) concepts of narcissism and melancholia can be seen to influence both his psychiatric and his political writings, their point of convergence being his trenchant critique of the pathogenic effects of racism and colonial oppression.

\section{Dr Fanon: From Saint-Alban to Bilda-Joinville}

Thankfully, there is an emerging body of scholarship that attempts to give psychoanalytically-inclined psychiatry its rightful place in the development of Fanon's thought. Much of this work is, naturally, in French (see Maspero: 1964; Postel and Quetel: 1994; Cherki: 2000; Razanajao and Postel: 2007; Khalfa and Young: 2015), but it is appearing with gathering momentum in English too (Adams: 1970; Bulhan: 1985; Macey: 2012; Khalfa: 2015; Ludis: 2015). ${ }^{2}$ Here then, I will only give a brief outline of Fanon's relation to psychiatry, in order to pave the way for a reflection on narcissism in Black Skin, White Masks and melancholia in The Wretched of the Earth.

Fanon's colonial education ensured that his initial imaginary encounter with France came via the revolutionary ideals of liberté, egalité and fraternité, and it was probably this idealism that led him to join the Free French Army to fight for the "mother country' in 1944 (see chapter 3 of Macey: 2012). His first real encounter with war-torn Europe then was a shock: it was in Paris, not his hometown of Fort-de-France, that he

under the same heading as the French strand which was much more philosophically complex, implied a very different politics, and was also less inclined to accept a 'mythical' reading of madness.

${ }^{2}$ To this list we will soon be able to add the forthcoming title Frantz Fanon, Psychiatry and Politics, jointly written by Nigel Gibson and Roberto Beneduce, which will provide a sustained focus on Fanon's clinical writings in English. 
first experienced the 'epidermal' racism that would prompt the writing of Black Skin, White Masks. Although this precipitous fall of the ideal of French egalitarianism was by his own account deeply painful, it seems that it was Fanon's passion for medicine that encouraged him to return to France in 1946. He studied medicine at the University of Lyon between 1947 and 1951, where he heard lectures by Maurice Merleau-Ponty and, after belatedly choosing to specialise in psychiatry, became influenced by the-then current phenomenological psychiatry that drew on Husserl, Heidegger and Karl Jaspers. As we will see, this phenomenological orientation exerted a strong influence on Fanon's approach to the lived experience of racism.

During his time in Lyon, Fanon also engaged closely with debates opened up by neurologist, psychiatrist and psychoanalyst, Henri Ey, who posed urgent questions about the relationship between neurology and psychiatry. These were also questions about the etiological place of biology in relation to the psychosocial model pioneered by psychoanalysis. Fanon's final, rather rushed dissertation ${ }^{3}$ focussed on exactly the issue Ey raised of the interactions between brain-based illnesses on the one hand, and mental disorders of a psychological nature on the other. He leant quite heavily, though not uncritically, on Ey's attempted articulation of these in his theory of 'organo-dynamic psychiatry' (Ey: 1975). By taking a hereditary and degenerative condition called Friedreich's ataxia as his focus, Fanon's dissertation tested "the reducibility of the mental to the neurological" and, foreshadowing future concerns, ultimately ended up showing "the relational - and by extension social - dimension of the development of mental illness" (Khalfa: 2015, 56). In other words, Fanon already argued that the psyche must be situated in its social context. He defended this dissertation in November of

\footnotetext{
${ }^{3}$ It was rushed because his supervisor, Professor Dechaume, had perhaps understandably refused to endorse a version of Black Skin, White Masks as an acceptable dissertation submission.
} 
$1951,{ }^{4}$ thereby earning the right to practice as a psychiatrist. Despite the Rubicon narrative previously mentioned, he would continue to publish on psychiatric issues right up until 1960, just a year before his death, and indeed to practice clinically within the Health Divisions of the Algerian Army of National Liberation.

Soon after the defence of his dissertation, Fanon was accepted on to a residence programme at the Hôpital Saint-Alban-sur-Limagnole, in the département of Lozère, where he would work for another two years. This experience had an absolutely formative effect on his ideas about the overlaps between psychiatry, the institution, and wider society. For it was at Saint-Alban that he came into contact with François Tosquelles whose personal and professional trajectory would be echoed in many ways by Fanon's own. A psychiatrist and psychoanalyst from Catalan, Tosquelles was also an immigrant and a militant activist: he fought for the Republicans in the Spanish Civil War, but was forced to flee to France in 1939 after Franco condemned him to death, crossing the Pyrenees on foot to take up a post at the Saint-Alban hospital (technically as a psychiatric nurse in the first instance, since his Spanish qualifications were not recognised in France). As well as being a key figure in Saint-Alban's legendary role during the Résistance, he completely transformed psychiatric practice there, developing an approach that he called 'sociothérapie', but which came to be better known in France as 'psychothérapie institutionnelle' or 'institutional psychotherapy' (for an overview of the emergence of this movement, see Ayme: 2009).

Institutional psychotherapy experimented with psychoanalytic approaches to the treatment of psychosis in institutional contexts recognised to be in dire need of reform. It mixed an 'anti-psychiatry' style critique of the carceral asylum system as itself

\footnotetext{
${ }^{4}$ Only one chapter of this dissertation was ever published as a journal article (see Fanon: 1975) and Fanon doesn't make reference to it himself in his subsequent writings.
} 
pathogenic, with both a psychoanalytic ethics of the singularity of every human being, including those suffering mental distress, and a broadly Marxist emphasis on human being as fundamentally social being (Reggio and Novello: 2007; Mackie: 2016). In keeping with what has become a much broader tradition of therapeutic communities, institutional psychotherapy attempted to create a horizontal, collective and democratic social milieu, in order to cure at once the psychiatric patient and the sick asylum system. Tosquelles was one of the founding members of the Groupe de travaille de psychothérapie institutionnelle which would find, in the 1960s and beyond, a more famous home at La Borde clinic, and an equally militant spokesperson in Félix Guattari (future collaborator, of course, with Gilles Deleuze). The other key figure at La Borde, Jean Oury, had also been an intern at Saint-Alban under the inspiring tutelage of Tosquelles. This remarkable man, then, became Fanon's mentor, and it is clear that he exerted a profound influence over his thinking, both as a psychiatrist and a militant. They gave several joint conference papers drawing on the innovative techniques they were developing at Saint-Alban (Khalaf: 2015).

Nonetheless, one can go too far with this idea of a simplistically 'progressive' psychiatric avant-gardism in Fanon's case: awkwardly for some within critical psychiatry today, Fanon supported and made extensive use of electro-shock treatments, was an early adopter of narcoleptics like lithium, and even advocated insulin-induced comas (though he always viewed these methods as enabling psychoanalytic or at least psychotherapeutic work, rather than as ends in themselves). The overall position outlined in his psychiatric writings remained rather closer to Ey's organo-dynamic theory than to Lacan's structuralist emphasis on the Other of language, though I will be exploring important tensions in Fanon's relation to these two frameworks here. Nonetheless, he was certainly on the inside of these radical currents within French 
psychiatry, indicating that between his politics and his psychiatric practice, there was much more continuity than discontinuity.

By 1953 however, Fanon was growing disillusioned with the racism even of the French Left (see Ludis: 2015) and made the fateful decision to take a job in Algeria, where he took up the post of chef de service in the aforementioned Bilda-Joinville psychiatric hospital. There he innovated well beyond the parameters his mentor's sociothérapie because what he found forced him to. He took over two spatially but also ethnically divided wards: on one side the Europeans, on the other, the 'indigènes'. This hospital-based apartheid reflected the racist ethnopsychiatry of Antoine Porot, himself trained at the University of Lyon though many years before Fanon. Porot had established the Algiers School of Psychiatry in 1925 precisely, it seems, to legitimise the brutal nature of French rule over an Arab population deemed to be inherently inferior, biologically but also psychologically (Gibson: 2003; Mahone and Vaughan: 2007; Keller: 2007; Macey: 2012). Fanon's critique of Porot's 'indigenous psychiatry' in The Wretched of the Earth was so excoriating because he had seen its consequences in his own hospital. Needless to say, he immediately set about deconstructing the spatial, temporal and organisational manifestations of Porot's racist binaries applying to the letter Tosquelles' 'social therapy' techniques to do so. Although stories of Fanon immediately relieving inmates of their straightjackets (Gendzier: 1973) are no doubt apocryphal (see Bulhan: 1985 for a corrective), he did quickly set up a music appreciation society, a film club, and even a hospital journal, all run by the patients themselves. He also involved them in building a football pitch in the grounds for their own use. However, what really set Fanon down a path we might now think of in terms of cross-cultural critical psychiatry was the starkly uneven response to these social therapeutic methods adapted from Tosquelles. As he reflected in an article co-written 
with Jacques Azoulay at the time (Fanon and Azoulay: 1954), the 'European' ward (a female ward) responded extremely well to these initiatives, yet the 'Indigenous' ward composed of Algerian Muslim men, did not: they remained sullen, disengaged and withdrawn.

Of course, Fanon would not appeal to Porot's almost eugenic ideas to explain this phenomenon, any more than to the related 'North African syndrome' he had decried in his very first academic publication (reproduced in Fanon: 1967, 3-16). Instead, he began to explore the importance of the cultural dimension of his new setting in addition to the social one that Tosquelles had stressed. Fanon realised that the activities he had organised could not possibly have the same cultural salience for the Muslim Algerian men in the 'indigenous' ward as they might for the mostly Catholic European women. Nor, indeed, would these men share the same conception of mental illness and health as the one imposed on staff by a colonial training system. He took it upon himself to consult anthropological literature on indigenous North African practices and cosmologies, particularly their framing of mental illness, to better understand his patients and their cultural milieu. Newly informed, he then experimented not just with sociotherapeutic but also with what could crudely be called 'culturotherapeutic' activities. He arranged for local storytellers to perform in the hospital as well as local musicians; he integrated celebrations of religious festivals into ward-life; he set up a café maure which served traditional mint tea and sweet pastries; he encouraged the involvement of family and friends to reflect the less individualistic and more communal Arab culture (Macey: 2012). It was as if the walls separating the psychiatric from the general population were dissolving, or at least becoming much more permeable. Jean Khalfa refers to this bold experiment as "a complete reversal of the ethnopsychiatric gaze" (Khalfa: 2015, 66). 
Although clinically successful, opening his wards to the world in this way inevitably invited in the violence and brutality of the worsening independence struggle. Fanon stuck to the humanism of his Hippocratic oath, treating police and members of repressive para-military groups with just as much care as the nationalist revolutionaries whose cause he more and more fervently supported. However, as the oppression of FLN militants and their sympathisers intensified after 1954, the shift from the social to the cultural that Fanon had enacted at Bilda-Joinville inexorably brought him up against the political sphere. Of course, his position had always been that one cannot separate these domains in any case.

\section{On Colonial Narcissism}

Now that we know $D r$ Fanon a little better, as a radical psychiatrist who was also at least passingly familiar with Freudian and post-Freudian psychoanalysis, we can turn to the relevance of the concepts of narcissism and melancholia for his simultaneously critical and clinical writings. While I certainly don't want to go as far as proclaiming him to be “an apprentice Lacanian” (Macey: 2012, 140), I do want to foreground the impact of Jacques Lacan's reformulation of Freudian narcissism on Fanon's theorisation of the dialectic between coloniser and colonised in Black Skin, White Masks.

There is no doubt Fanon was aware of some of Lacan's ideas well before he (Lacan) became such a notorious figure. Fanon's dissertation devotes a whole section to Lacan, referring to his 1932 thesis on paranoia in the case-study of 'Aimée' (when Lacan himself was still a psychiatrist rather than a psychoanalyst); to his 1938 text on the family which had been reproduced in the Encyclopédie française and was thus very widely available; but particularly to his barbed critique of Ey's 'organo-dynamic' psychiatry which was originally given as a paper at a 1946 conference organised by Ey 
himself (Lacan: 2006a). This last was particularly pertinent for Fanon's dissertation insofar as it focussed on psychic causality, providing a counter-point to Ey's emphasis on organic causation with an already structuralist understanding of the psychogenesis of symptoms. Tosquelles, too, would have encouraged Fanon to engage with Lacan, no doubt with an eye to linking psychogenesis to sociogenesis. According to David Macey (2012: 144), Tosquelles was part of a reading group in the Catalan city of Reus that studied Lacan's thesis on 'Aimée': when he crossed the border into France, one of only two books he was carrying was a well-thumbed copy of Lacan's thesis. Once in SaintAlban, Tosquelles wrote to Lacan himself to let him know that he was circulating 'homemade copies' of the text among staff there, and it is quite possible that Fanon came by his copy this way even before meeting the Spaniard in person (Macey: 2012, 139). Prior to Tosquelles' influence however, Fanon included a long footnote precisely on Lacan's mirror stage argument in the chapter entitled 'The Negro and Psychopathology' in Black Skin, White Masks (1986: 161-164), to which we shall turn in a moment.

A note of caution before doing so, however. Within the field of postcolonial studies generally, the links between Fanon and Lacan have arguably been grossly exaggerated, thanks to the uptake of Lacanian theory in the academy as a kind of allpurpose cultural and/or political theory in ways that Lacan himself would no doubt have mocked as 'university discourse' (Lacan: 2007). ${ }^{5}$ For example, Homi Bhabha's extremely influential reading of Fanon in Locations of Culture (1994) undertakes a

\footnotetext{
${ }^{5}$ Lacan formalises four discourses (adding a fifth, that of the capitalist, a couple of years later), the specificity of 'university discourse' being that it situates knowledge in the position of mastery. As well as anticipating the rise of technoscience, Lacan's matheme of university discourse is useful precisely because it shows its fundamental difference from analytic discourse, which has a completely different relation to knowledge.
} 
strongly Lacanian re-framing of his entire oeuvre, but I would say in a very 'theoreticist' vein, and with little or no sensitivity to historical context or the points of clinical overlap between the two men. In Bhabha's hands, Lacan seems more of a Derridean poststructuralist literary theorist than a practicing psychoanalyst, while Fanon's Maoism is set aside in favour of a textualist model of political agency it is very hard to imagine the FLN militant endorsing. Nonetheless, specifically around the notion of colonial narcissism, Bhabha is evidently right that there is a genuine encounter with Lacanian ideas that warrants close attention. Indeed, more recent theorists, such as Mikko Tuhkanen (2010), have managed to productively re-visit the relevance of Lananian theory for critical race studies in ways that avoid over-stating the 'anxiety of influence' between Lacan and Fanon which seems, in fact, to have been very minimal.

In any case, thanks to the above-mentioned footnote in Black Skin, White Masks, we are on safe textual ground. In it, Fanon refers directly to "Lacan's theory of the mirror period" (1986, 161). The paper reproduced in the Écrits (Lacan: 2006b) is actually a version of a talk originally given in 1949, yet Lacan's first public outline of it goes as far back as 1936. In all of these iterations, he can be seen to be developing a response to a question posed by Freud's 1914 text, 'On Narcissism: An Introduction' (Freud: [1914c] 1957, 67-102): namely, what prompts the transition from primary narcissism to secondary narcissism and object-cathexis? In other words, why would we ever give up the quintessentially narcissistic position Freud memorably described there as that of 'His Majesty the baby' (91), opening ourselves up to the risks of libidinal investment in others, either by way of identification or as objects of the sexual instincts? As early as 1909, Freud had posited narcissism as a necessary stage between auto-eroticism and object choice before his colleagues in the Vienna Circle (Jones: 1955, 304). Five years later in 'On Narcissism,' he introduced the new distinction between 'ego-libido' and 
'object-libido' (Freud: [1914c] 1957, 76), and observed that "there must be something added to auto-eroticism - a new psychical action - to bring about narcissism" (77). It was to the question of what this 'something' was that Lacan was responding in his mirror stage argument.

That this question remained rather obdurate for Freud himself arguably stemmed from the fact that he did not always succeed in escaping from a Darwinian conception of the ego, with reference to an organism dominated by a survival instinct: the opening of 'On Narcissism' glosses it as "the egoism of the instinct of self-preservation" (74). For Lacan however, the very structure of the ego needs reconceiving on the basis of a completely different topology, one that holds at bay the threat of biological reductionism. The ego is not there from birth, nor does it emerge as an adaptive response to an experiential reality-testing, as Freud sometimes suggests. Rather, it is dialectically entangled in an Other whose recognition is a condition of the ego's very being, as well as the cause of its constitutive alienation from it. The psychical action that needs to be added to auto-eroticism in order to bring about narcissism then, is the mirror phase.

Though probably familiar to most readers, a quick summary of Lacan's argument should clarify what Fanon found so useful in it. Drawing on preceding work on mimicry by Henri Wallon and on childhood transitivism by Charlotte Bühler, Lacan makes three key inter-related claims. Firstly, that the human baby is born prematurely in comparison to most other animal species, and thus in a state of radical dependency on its caregiver (Lacan: 2006b, 75). This dependency stems in part from a complete lack of motor coordination: the human baby is little more than a chaotic bundle of libidinal drives. It has no conception of a self-Other distinction with which to regulate or apportion these drives. Secondly however, a bounded sense of self with which to contain its drives does begin to emerge around six to eighteen months of age, thanks to the external support 
given by a reflective surface, such as (but not confined to) the titular mirror. Such surfaces gradually provide a correspondence between visual perceptions and direct bodily experiences of motility, giving the body a coherent image on the basis of which to establish an ego distinct from the (m)Other. This operation is behind the emergence of a second-order self-consciousness beyond the immediate but unreflexive consciousness possessed by animals. To put this simplistically, the pain of hunger, for example, can cease to be an alien and unpredictable force to become my hunger, and thus something that can enter into the dialectic of demand and desire addressed to an Other through a cry which already has symbolic dimensions. Crucially however, Lacan also insists on a third element: in order for the binding of an ego to an image in what he calls "the imago" (76) to be fixed, this Other has to give its seal of approval in some way, uttering something of the order of a 'yes, that's you!'. In a very fundamental sense then, Lacan argues that the ego receives its being from the 'outside', from the Other.

One of his reference points here - as also for Fanon, but from a more phenomenological perspective - is obviously a certain reading of Hegel. The Kojévian interpretation of Hegel's Phenomenology of Mind was enormously influential on French intellectual life in the first half of the $20^{\text {th }}$ century, including on Lacan who attended these lectures himself in the 1930s (see Roudinesco: 1993). Just as Hegel's account of the master-slave dialectic in the Phenomenology suggests a dynamic and relational form of subjectivity with a 'struggle for recognition' at its core, so Lacan suggests, from a psychoanalytic rather than a philosophical perspective, that the ego's very being is not given by nature from the outset but is rather granted by and through this Other. Beyond Hegel moreover, Lacan would stress not a mutual recognition between self and Other, 
but a structural misrecognition without the consolation of a future aufhebung [sublation] ${ }^{6}$ in the Absolute. Thus, for Lacan the resulting ego is, in its imaginary dimension, fundamentally illusory, the site of a deceptive inauthenticity relative to desire and the subject of the unconscious.

We could say that the mirror is two-sided then. It is only thanks to the articulation of both sides that the mirror function enables the ego to situate itself relative to the two axes Freud already outlines in 'On Narcissism'; namely, the 'ideal-ego' and the 'egoideal'. ${ }^{7}$ The first side of the mirror, as it were, provides an ideal-ego that gives a sense of a body localised in space and thus a place from which 'I' am seen by others. But the other side of the mirror, which is also that of the Other, establishes an ego-ideal - a concept posited by Freud for the first time in 'On Narcissism' but later to become the better known 'super-ego' in the second topography and a crucial element in his arguments in Civilization and its Discontents. It is this ego-ideal that imparts an often

\footnotetext{
6 'Sublation' is the standard translation of this Hegelian term, though it carries a number of other meanings including 'transcending' and a paradoxical combination of 'abolishing' and 'preserving' within the same movement, but the main meaning centres on a picking up or carrying over to a higher level. Certainly for 'Right Hegelians' the movement of aufhebung is one of teleological progress in which the negative is eventually annulled in the Absolute. In this respect, Lacan is much more of a 'Left Hegelian' in that such a final resolution would be an imaginary fantasy covering over the structural persistence of the negative as lack. For a sustained consideration of the Hegel-Lacan relation see Žižek: 2014.

${ }^{7}$ The difference between the ideal-ego and the ego-ideal is perhaps clearer in Lacan than it is in Freud, thanks to his distinction between the imaginary and the symbolic. Lacan represents the difference in his characteristic algebra as 'i(a)' and 'I(A)' respectively. We can think of i(a) or the ideal-ego as the narcissistic identification with, and investment in, an image of plenitude linked to that jubilatory 'thou art that!' moment central to the mirror stage; whereas I(A) or the ego-ideal emphasises the symbolic dimension of this egoic being which necessarily entangles it in an anxious interpretation of what an authoritative Other wants.
} 
anxious sense of what 'I' should try to be in the eyes of the Other on which the 'I' depends for its consistency. One side of the mirror then provides a place and a purpose within a coherent 'reality', but there is a recto to this verso. The resulting fantasies about what one should be or do for the Other ensnare desire in alienating identifications that end up exhausting neurotics in particular in their search for an impossible wholeness.

It should be immediately obvious why this notion of an illusory ego imposed by an alienating Other was immensely useful to Fanon in his reflections on the effects of internalised racist stereotypes in the colonies. However, as with his use of Marxism, Fanon was well aware of the dangers of an uncritical transposition of psychoanalytic concepts into the colonial context, as his critique of Octave Mannoni's Prospero and Caliban demonstrates (see chapter 4 of Fanon: 1986). Thus, the chapter entitled 'The Negro and Psychopathology' in Black Skin, White Masks opens with a reference to Lacan's text on the family (Fanon: 1986, 141), but precisely in order to go on to critique the universalising tendencies of psychoanalysis when unreflexively grounded in Eurocentric assumptions about the family - "Like it or not," he boldly asserts, "the Oedipus Complex is far from coming into being among Negroes" (151-152). Nonetheless, the centre-piece of the chapter is a contextualised use of Lacan's (Hegelian) mirror stage argument, in order to isolate the structure of black identity in the colonies: "The goal of [the black man's] behaviour will be The Other (in the guise of the white man), for The Other alone can give him worth" (154). It is this notion of racialised narcissism that is explored in the footnote on the mirror stage (161).

In it, Fanon's insight as a fledgling psychiatrist is apparent, for he initially situates Lacan's discussion of narcissism in its relation to psychosis rather than to 
neurosis. ${ }^{8}$ In effect, and in surprising anticipatory accord with Lacan's third seminar on the psychoses (Lacan: 1997) which did not take place until three years after the publication of Black Skin, White Masks, Fanon acknowledges the construction of a persecutory Other in paranoid delusions as a means of reconstituting an ego that has suffered the decomposition of a psychotic break: as he aphoristically puts it, "Whenever there is a psychotic belief, there is a reproduction of self" (161). In many ways, this is classically Freudian in its echoes of the Schreber case, yet Fanon's interest here is far from classic: it is in the role of the figure of the Negro in this process of delusional stabilisation in white psychotics, as potential support for his claim that "The Negro is a phobogenic object" (151). ${ }^{9}$ If, as Freud's Little Hans case suggests, phobia partially succeeds in localising an otherwise generalised (castration) anxiety in a phobogenic object (horses for Little Hans), could the culturally hyper-cathected figure of the Negro, as bestial and terrifyingly potent sexually, serve a related function in the repressed and repressive psyche of the coloniser?

\footnotetext{
${ }^{8}$ Thanks to the commonplace understanding today of 'narcissism' as a kind of preening self-regard, it is often forgotten that Freud's 'On Narcissism' opens up the general question of narcissism via a discussion of the withdrawal of libido from 'reality' observable in dementia praecox, or schizophrenia. Freud had long categorised dementia praecox as a 'narcissistic neurosis', as opposed to the properly neurotic 'transference neuroses' treatable by psychoanalysis.

${ }^{9}$ This thesis regarding the phobogenic status of the Negro may have derived from Fanon's direct clinical experience at the Saint Ylié hospital in Dôle between the end of his psychiatric studies in Lyon and the start of his placement at Saint-Alban. This was when he encountered 'Mlle B.', a 19 year old woman who suffered facial tics and spasms and complained of hallucinations of concentric circles, always to the sound of "Negro tom toms" (Fanon: 1986, 205). Sessions with this patient revealed the presence of a group of dancing black men preparing to boil and eat a white man.
} 
However, Fanon's interest soon turns in this footnote to the specificity of the narcissism he discerns in the Antilles of his youth. It is here that he pursues the implications of Lacan's notion of narcissism when understood - as it must be once the role of the Other is acknowledged - as both social and indeed political, rather than merely 'psychological'. He notes that even in the dreams and "hypnagogic hallucinations" (162) of Martinicans, their blackness remains absolutely unmarked or "neutral". This is because at the level of everyday life, they constantly compare themselves and each other to a white ego-ideal (an argument Fanon has already outlined earlier in the chapter, through a polemic with Alfred Adler). He cites several scenarios that illustrate this. Antillean children write in their schoolbooks of having "rosy cheeks" (ibid.); at the cinema, they identify with Tarzan against the Negroes (152); and even as adults their everyday speech reflects a colour-coded value-system imported by the French, as in phrases such as "He is black but he is very intelligent" (163) or "They're very black, but they're all quite nice" (164), and the derogatory use of "blue" to describe the darkest skin pigmentation.

It is only when the Martinican goes to France or encounters whites that the fact of his blackness will suddenly be felt. It will be felt in the reduction of his or her subjectivity to the skin-deep superficiality which is all that this white Other recognises, leading to a dissolution of the ideal-ego or body-image as well as to a profound disorientation with regard to the ego-ideal (what am I for the Other?); in other words, to a catastrophic failure of narcissism. It is as if when one side of the mirror shatters, the other must follow: when 'I(A)' or the ego-ideal clearly demands a whiteness the black body can no longer attain, the 'i(a)' or ideal-ego dissolves into a body deprived of consistency by the Other. This is the experience that Fanon uses a Sartre-inspired phenomenology to capture in the famous 'Look mummy, a Negro!' scene, when, of his 
own fragmenting bodily integrity, he exclaims, "the corporeal schema crumbled, its place taken by a racial epidermal schema" (112). The overall trajectory of the footnote on Lacan's mirror stage in Black Skin, White Masks implies that this experience of racism is akin to a psychotic decomposition of egoic coherence.

\section{Violence and Melancholia}

I want to turn now to the later, very different text, The Wretched of the Earth. This work bears all the hallmarks of the circumstances of its production, written as it was at the height of the Algerian war of independence as well as coinciding with the decline in Fanon's health. Where Freud and Freudians are a major reference point throughout Black Skin, White Masks, in this book, it is a Maoist interpretation of Marx and Marxism that drives the argument forward. The result is an acute analysis of, among other things: the violence of colonial oppression; the dialectical transformation of this violence into armed resistance; the ambiguous role of 'native' bourgeois intellectuals in independence struggles; the pitfalls of regressive appeals to pre-colonial traditions in cultural forms of nationalism; and - very presciently from today's globalised perspective - the persistence of economic forms of dependence after nominal independence. The Wretched of the Earth, then, is a manifesto of Third World Marxism and a practical handbook for the anti-colonial militant.

And yet, psychiatry remains a decisive element in this text too, as evidenced by the final chapter entitled 'Colonial War and Mental Disorders' (Fanon: 2001, 200-250). Fanon notes the incongruous appearance of this conclusion in such an ostensibly political work, but he seems resigned to it, as if to an indelible aspect of both himself and the reality of the situation: "Perhaps these notes on psychiatry will be found ill-timed and singularly out of place in such a book; but we can do nothing about that" (200). Far 
from being an after-thought however, I would suggest that the inclusion of this chapter demonstrates the strong underlying consistency of Fanon's concerns, arguably dating back to his 1951 dissertation and shaped by his association with Tosquelles. I would agree, then, with Gwen Bergner's assertion that "Fanon's return to the psyche toward the end of The Wretched of the Earth signals his continuing demand that we explore the interdependence of nation and subject" (Bergner: 1999, 220).

To this end, 'Colonial War and Mental Disorders' consists in a series of clinical case-studies or vignettes of varying length, which Fanon gathers under the umbrella psychiatric heading of 'reactionary psychoses'. Contemporary equivalents of this category would be 'brief reactive psychosis' or 'situational psychosis', the common denominator being a stress on an external and contingent triggering factor, rather than some hereditary or constitutional predisposition, as well as on the transience of the symptomatology. Fanon appeals to this term, it seems, primarily to emphasise the pathogenic causality of the colonial war itself, and thus to support his long-held position on the sociogenesis of many mental disorders which informed his experiments in psychothérapie institutionnelle. In the context of Algerian psychiatry, the category of reactionary psychosis also had the added benefit of putting at arm's length Porot's dominant ethnopsychiatry, which would be quick to biologise and even essentialise indigenous pathologies. Indeed, Fanon's overall approach in this chapter arguably prefigures the politicised use of 'Vietnam Syndrome' as an element of anti-war discourse in the US in the 1970s, later to be recognised, for better or for worse, as PostTraumatic Stress Disorder (Young: 1995; Summerfield: 2001).

Fanon organises these clinical cases of 'reactionary psychoses' into three sections with a clear trajectory. The first section groups five cases involving both Algerians and Europeans who have clearly been directly affected by the violence of the 
war itself, either as combatants and torturers or as victims. It is important to Fanon's Marxist but also 'medical' humanism that he includes cases representing both sides of the conflict. The second section gathers five more cases that reflect a more diffuse atmosphere of violence and tension in the context of a 'total war' that cannot be limited to direct combat or combatants per se (this group includes behavioural problems among children, for example). Finally, and in very fragmentary form, Fanon lists the respective mental disorders that seem to correspond to the various modes of torture that were raised by the French army to a kind of horrific Sadean art during the Algerian conflict (for an unflinching history of this, see Lazreg: 2007).

Beyond the overarching strategic category of 'reactionary psychoses' however, I want to suggest that there are strong grounds for framing the clinical data Fanon outlines in this chapter in terms of the classic presentation of Freudian melancholia. His clinical notes refer to "a mass attack against the ego" (203); "prolonged insomnia [...] anxiety and suicidal obsessions" (ibid.); "a thoughtful, depressed man, suffering from loss of appetite, who kept to his bed" and "showed a marked lack of interest" as well as sexual impotence (206); another's "chest was lifted by continual sighs [...] two attempts at suicide since the trouble started" (210); "they shun contact" (227); "Apathy, aboulia, and lack of interest" (228); patients who are "inert, who cannot make plans, who live from day to day" (ibid.), and so forth. This overall clinical picture corresponds rather precisely to Freud's description of the "distinguishing features of melancholia" in his 1917 text, 'Mourning and Melancholia' (Freud: [1917e] 1957, 243-268): “a profoundly painful dejection, cessation of interest in the outside world, loss of the capacity to love, inhibition of activity, and a lowering of self-regard to a degree that finds utterance in self-reproaches and self-revilings" (244). 
However, here one should be cautious. Freud himself was always concerned to push beyond merely descriptive psychiatry, with its tendency towards catch-all syndromes, in an effort to isolate the underlying psychic mechanism. Thus, it is worth reminding ourselves of the more 'structural' psychoanalytic argument in 'Mourning and Melancholia'. As the title suggests, Freud organises his discussion around the comparison with mourning suggested to him by Karl Abraham. Many of the presenting problems are similar, though with an important and revealing difference: those who have suffered a bereavement do not usually display the vehement and often voluble selfdeprecation of the melancholic, who frequently presents himself as "worthless, incapable of any achievement and morally despicable" (246). People in mourning are also generally conscious of the loss that has occasioned their grief, whereas the melancholic does not know from whence his feelings of despair and self-disgust originate. To Freud, this suggests three things: firstly, that the nature of the loss in melancholia is of the order of an ideal (245); secondly, that an economic process similar to mourning takes place in the unconscious system rather than the conscious one (246); and thirdly, that in the "clinical picture of melancholia, dissatisfaction with the ego on moral grounds is the most outstanding feature" $(247-248)$. The ideal nature of the objectloss involved in melancholia calls for fine clinical distinctions, since it opens up the field of possible losses well beyond bereavement, to include all manner of libidinally invested abstractions. Of relevance to Fanon's focus on colonised peoples is Freud's reference to "one's country, liberty, an ideal" (243) as among the possible object-losses at the root of a melancholia.

Showing his courage as a clinician, Freud makes two related observations about therapeutic work with melancholics: firstly, that it is of more clinical value to confirm the patient's accusations of being worthless as psychically real, than it is to deny them 
with counter-evidence from a supposedly objective reality (246-247); and secondly, that if one situates the insistent self-reproaches in the broader context of the patient's biography, one quickly sees that the reproaches can be applied word for word to some significant other, usually a loved one. Thus, "the self-reproaches are reproaches against a loved object which have shifted away from it on to the patient's own ego" (248). This puts Freud on the scent of the role in melancholia of the very withdrawal of libido along pathways laid down by narcissism he had identified in the 1914 text 'On Narcissism'. It also alerts him to the related division of the psyche in to an ego and a persecutory 'moral' agency which will later become the super-ego. In this way, he arrives as his metapsychological hypothesis regarding melancholia: in it, there has been "an identification of the ego with the abandoned object" and thus, in the famous phrase, "the shadow of the object fell on the ego" (249). In melancholia then, we have a particular mechanism for dealing with what Freud calls, here as elsewhere, a "conflict due to ambivalence" (251): because the lost object was always both loved and hated at the level of the unconscious, one way of attempting to retain it as ideal is to internalise and direct against the ego the portion of hatred and aggression which had always been the object's secret obverse. This self-directed sadism helps to explain the propensity to suicide amongst melancholics, since in killing themselves they are actually taking indirect revenge on the lost object: "the ego can kill itself only if, owing to the return of the object-cathexis [..] it is able to direct against itself the hostility which relates to an object" (252). This involution is possible because the original object-choice had a narcissistic component, which is to say, melancholic reproaches can be directed against the self because the lost object was 'loved' (but also hated) via a fundamentally narcissistic identificatory pathway in the first place. One almost has the image of an 
elastic band: as libidinal cathexis stretches out from the ego towards an object, it can also snap back violently along the same trajectory.

Returning to Fanon, we can see that this melancholic mechanism for internalising a primordial violence has a general pertinence in the colonial context. The first two chapters of The Wretched of the Earth deal with the issue of violence, the repressive violence of colonial power and its inscription in the very sinews of the black body, as well as the diverse ways in which that violence tries to find indirect expression. Fanon is eloquent about the phenomenon of hyper-tension amongst colonised blacks, as well as the tendency to inter-tribal or 'black-on-black' violence during certain phases of decolonization struggles. Such incidents are used by the colonising powers to prop up the image of the 'uppity native' legitimising their rule, yet they are really the dialectical consequence of it: "collective auto-destruction in a very concrete form is one of the ways in which the native's muscular tension is set free" (Fanon: 2001, 42). Does this not remind us of the suicidal tendency in melancholia noted by Freud? It is also connected to the violent rivalry Lacan recognises as an inherent aspect of the imaginary and thus the ego, as early as his 1932 thesis on 'Aimée' (who stabbed a famous Parisian actress with whom she identified) but also in his 1948 paper on 'Aggressiveness in Psychoanalysis' (Lacan: 2006c) in which aggression is once again correlated to narcissistic identification. Fanon also identifies a kind of sublimated form of this colonial violence in the recourse to superstition and 'wild' shamanic rituals. Among these, the spiritual 'takeover' of possession could be said to be a displaced symbolisation of colonial domination, with exorcism representing a kind of staged expiation (Fanon: 2001, 45). However, echoing the 'stuckness' of the arrested mourning characteristic of Freudian melancholia, Fanon suggests that the displaced modalities of colonial violence in each of these 'cultural' solutions merely "turn in the void" (ibid.). 
At this level, it is possible to discern in The Wretched of the Earth an implicit sociocultural, not simply 'individual', diagnosis of a colonial form of melancholia, a condition it is very tempting to neologistically term 'melancolonia'. How would one treat such a disorder?

\section{Towards a National Community of the 'New Man'}

In the broader field of postcolonial and critical theory, there has in fact been an appeal to the category of melancholia as a way of framing the contemporary persistence of the colonial past in the allegedly post-colonial present. In Postcolonial Melancholia for example, Paul Gilroy (2005) draws less on Freud and more on Alexander and Margarete Mitscherlich's The Inability to Mourn: Principles of Collective Behaviour (1975). This book examined Germany's post-war difficulties with confronting its Nazi past, but Gilroy refers to it in order to upbraid post-9/11 Britain's related inability to let go of its memories of Empire, and to highlight the ways in which this continues to sustain a xenophobic discourse around the figure of the immigrant. ${ }^{10}$ For Gilroy, inspired precisely by a certain reading of Fanon's humanism, the solution to this postcolonial melancholia lies in a multicultural "conviviality" (Gilroy: 2005, xv) that can lay the foundations for a planetary cosmopolitanism.

Notwithstanding the merits of Gilroy's vision, I would argue in closing that Fanon himself prescribed a quite different treatment for colonial - rather than postcolonial - melancholia, one that was much less compatible with the values of liberalism insofar as it focussed on the constitutive role of violence. It is certainly possible, as I have suggested, to identify a truly pathological form of melancholia that

\footnotetext{
${ }^{10}$ Gilroy's argument only seems more relevant today in the wake of the so-called 'Brexit' vote in June 2016 which was arguably decided on the basis of the figure (rather than the reality) of the 'immigrant'.
} 
Fanon sees as intrinsic to colonial forms of domination, but his suggested exit from that condition resembles less an improved mode of cosmopolitan cohabitation and more a kind of passage á l'acte in the Lacanian sense: a 'leap into the unknown', off the current stage, but also one with the capacity to create new possibilities, new destinies, new (national) communities.

The movement of decolonization theorised by Fanon in The Wretched of the Earth is simultaneously the creation of a new national community, one libidinally bound not by the kinds of imaginary identifications Freud identified in Group Psychology and the Analysis of the Ego (Freud: [1921] 1955) - a text that presciently maps the psychic foundations of the very Nazi period reflected on by the Mitscherlichs - but by a collective work of co-creation. In many ways, this emphasis on vital action resonates with a question Freud posed in 'Mourning and Melancholia' itself, when he wondered about the underlying economics of that "most remarkable characteristic of melancholia [...] its tendency to change round into mania" (Freud: [1917e] 1957, 253). Although today's psychiatry holds these together in the affective highs and lows of 'bi-polar disorder', the stakes for Fanon are rather different, since the transition from a depressive to a manic phase would relate to the emergence of a revolutionary subjectivity stirred to action.

Typically, this move beyond melancholia also involves a critical passage through colonial French psychiatry for Fanon. He notes a dilemma for the Algerian School of psychiatry when faced with the kinds of Algerian melancholics described in 'Colonial War and Mental Disorders':

[French psychiatrists] were accustomed when dealing with a patient subject to melancholia to fear that he would commit suicide. Now the melancholic Algerian takes to killing. The illness of the moral consciousness, which is always 
accompanied by auto-accusation and auto-destructive tendencies, took on in the case of Algerians hetero-destructive forms [...] This is the homicidal melancholia which has been thoroughly studied by Professor Porot in the thesis of his pupil Monserrat (241).

Fanon turns this racist ethnopsychiatry on its head by demonstrating the theoretical limitations inherent in its ideological function: "Since by definition melancholia is an illness of the moral conscience it is clear that the Algerian can only develop pseudomelancholia, since the precariousness of his moral sense are well known" (242). Thus, the pathologisation of Algerian violence in colonial psychiatry depoliticises it, yet in a way that also creates a blind-spot with regard to its dialectical transformation beyond a truly melancholic 'stuckness', into the revolutionary form of transformative violence that Fanon sees as a 'cure' for colonial melancholia. From the internalisation of the violence in the body of the colonised, we pass to the externalisation of this same violence against the colonial oppressor, and this passage from suicide to homicide is fundamentally 'healthy'. This is the "moment of the boomerang" (17) that Sartre identifies in his preface to The Wretched of the Earth, when European aggression is returned-to-sender; it is also the moment, for Fanon, of the birth of an independent nation.

Far from leaving psychiatry behind in order to become a revolutionary then, once his involvement in psychothérapie institutionnelle with its focus on social relations is appreciated, and once his critical engagements with the concepts of narcissism and melancholia are identified, one can see the mutually reinforcing relation between these two domains in Fanon's revolutionary thought. As I have tried to show in this chapter, Fanon is indebted to a Freudo-Lacanian understanding of narcissism in his elaboration 
of a specifically colonial form of narcissism organised around a racializing white Other. I have also tried to show that Fanon pushes critically beyond notions of Freudian melancholia that had become distorted by Eurocentric psychiatry, in order to posit an anti-colonial melancholia that can be dialectically transformed into a violent resistance with the potential to found a new, decolonised national subject. In this way, $\operatorname{Dr}$ Fanon can still show us how culture and clinic can and should coincide with critique.

\section{References}

Adams, P. (1970). 'The Social Psychiatry of Frantz Fanon'. American Journal of Psychiatry. 127: 109-114.

Alessandrini, A. (1999). Frantz Fanon: Critical Perspectives. London: Routledge. 
Ayme, J. (2009). 'Essai sur l'histoire de la psychothérapie institutionnelle'. Institutions. No. 44. 111-153.

Bhabha, H. (1994). Locations of Culture. London: Routledge.

Bulhan, H. (1985). 'Frantz Fanon: The Revolutionary Psychiatrist'. Race and Class. Vol. 21, No. 3: 252-271.

Cherki, A. (2000). Frantz Fanon, portrait. Paris: Éditions du Seuil.

Ey, H. (1975). Des idées de Jackson à un modèle organo-dynamique en psychiatrie. Paris: Privat.

Fanon, F. and Azoulay, J. (1954). 'La Socialthérapie dans un service d'hommes musulmans: Difficultés méthodologiques'. L'Information psychiatrique. Vol. 30, No. 9. Fanon, F. (1967). Toward the African Revolution: Political Essays. Trans. Haakon Chévalier. New York: Grove.

Fanon, F. (1975). 'Le Trouble mental et le trouble neurologique'. L'Information psychiatrique. Vol. 51, No. 10: 1079-1090.

Fanon, F. (2001). The Wretched of the Earth. Trans. Constance Farrington, London: Penguin.

Fanon, F. (1986). Black Skin, White Masks. Trans. Charles Lam Markmann, London: Pluto.

Freud, S. (1955). The Standard Edition of the Complete Psychological Works of Sigmund Freud, Volume XVIII (1920-1922): Beyond the Pleasure Principle, Group Psychology and Other Works, London: The Hogarth Press.

Freud, S. [1914c] (1957), 'On Narcissism', Standard Edition of the Complete Psychological Works of Sigmund Freud Volume XIV (1914-1916): On the History of the Psycho-Analytic Movement, Papers on Metapsychology and Other Works, London: Hogarth Press, pp.67-102. 
Freud, S. [1917e] (1957), 'Mourning and Melancholia', Standard Edition of the Complete Psychological Works of Sigmund Freud Volume XIV (1914-1916): On the History of the Psycho-Analytic Movement, Papers on Metapsychology and Other Works, London: Hogarth Press, pp.237-258.

Gendzier, I. L. (1973). Frantz Fanon: A Critical Study. New York: Grove.

Gibson, N. (2003). Fanon: The Postcolonial Imagination. London: Polity.

Gilroy, P. (2005). Postcolonial Melancholia. New York: Columbia University Press.

Jones, E. (1955). Sigmund Freud: Life and Work, Vol. 2. London: Basic Books.

Keller, R (2007). Colonial Madness: Psychiatry in French North Africa. London: University of Chicago Press.

Khalfa, J. (2015). 'Fanon and Psychiatry'. Nottingham French Studies. Vol. 54, No. 1: $52-71$.

Lacan, J. (1997). The Seminars of Jacques Lacan. Book III. The Psychoses. Trans. by Russell Grigg. London: W. W. Norton \& Company.

Lacan, J. (2006a). 'Presentation on Psychic Causality' pp.123-158 in Écrits: The First Complete Edition in English. Trans. Bruce Fink. London: W. W. Norton \& Company. Lacan, J. (2006b). 'The Mirror Stage as Formative of the I Function as Revealed in Psychoanalytic Practice' pp. 75-81 in Écrits: The First Complete Edition in English. Trans. Bruce Fink. London: W. W. Norton \& Company.

Lacan, J. (2006c). 'Aggressiveness in Psychoanalysis' pp. 82-101 in Écrits: The First Complete Edition in English. Trans. Bruce Fink. London: W. W. Norton \& Company. Lacan, J. (2007). Seminar XVII: The Other Side of Psychoanalysis. Trans. Russell Grigg. London: W. W. Norton \& Company.

Lazreg, M. (2007). Torture and the Twilight of Empire. Princeton: Princeton University Press. 
Ludis, P. (2015). Frantz Fanon: Philosopher of the Barricades. London: Pluto Press.

Macey, D. (2012). Frantz Fanon: A Biography. London: Verso.

Mackie, B. (2016). Treating People with Psychosis in institutions: A Psychoanalytic Perspective. London: Karnac.

Mahone, S. and Vaughan, M. (eds.) (2007). Empire and Psychiatry. London: Palgrave Macmillan.

Maspero, F. (2006). 'Note de 1'éditeur', pp. 7-10 in Frantz Fanon, Pour la revolution Africaine: écrits politiques. Paris: La Découverte.

Mitscherlich, A. and Mitscherlich, M. (1975). The Inability to Mourn: Principles of Collective Behaviour. London: Grove Press.

Postel, J and Quetel, C. (eds.) (1994). Nouvelle histoire de la psychiatry. Paris: Dunod. Reggio, D. and Novello, M. (2007). 'The Hospital is Ill'. Radical Philosophy. Vol. 143: $32-46$

Razanajao, C. and Postel, J. (2007). 'La Vie et l'œuvre psychiatrique de Frantz Fanon'. Sud/Nord. Vol. 22: 147-74.

Roudinesco, E. (1993). Jacques Lacan: Esquisse d'une vie, histoire d'un système de pensée. Paris: Fayard.

Summerfield, D. (2001). 'The Invention of Post Traumatic Stress Disorder and the Social Usefulness of a Psychiatric Category'. The British Medical Journal. Vol. 322. 95-98.

Tukhanen, M. (2009). The American Optic: Psychoanalysis, Critical Race Theory and Richard Wright, New York: SUNY.

Young, A. (1995). The Harmony of Illusions: Inventing Post-Traumatic Stress Disorder. New Jersey: Princeton University Press. 
Žižek, S. (2014). The Most Sublime Hysteric: Hegel with Lacan. London: Polity Press, 2014. 